\title{
Gradhiva
}

GRADHIV

Revue d'anthropologie et d'histoire des arts

1 | 2005

Haïti et l'anthropologie

\section{Prohibition, persecution, performance}

Anthropology and the penalization of vodou in mid-20th-century

Prohibition, persécution et représentation: anthropologie et pénalisation du vodou au milieu $\mathrm{du} \mathrm{XX}^{e}$ siècle

\section{Kate Ramsey}

\section{OpenEdition}

\section{Journals}

Electronic version

URL: http://journals.openedition.org/gradhiva/352

DOI: $10.4000 /$ gradhiva.352

ISSN: $1760-849 X$

\section{Publisher}

Musée du quai Branly Jacques Chirac

\section{Printed version}

Date of publication: 1 May 2005

Number of pages: 165-179

ISBN: 2-915133-08-5

ISSN: 0764-8928

\section{Electronic reference}

Kate Ramsey, «Prohibition, persecution, performance », Gradhiva [Online], 1 | 2005, Online since 10 December 2008, connection on 01 May 2019. URL : http://journals.openedition.org/gradhiva/352 ; DOI : 10.4000/gradhiva.352

This text was automatically generated on 1 May 2019.

(c) musée du quai Branly 


\title{
Prohibition, persecution, performance
}

\author{
Anthropology and the penalization of vodou in mid-20th-century \\ Prohibition, persécution et représentation: anthropologie et pénalisation du \\ vodou au milieu du $\mathrm{XX}^{e}$ siècle
}

Kate Ramsey

\section{AUTHOR'S NOTE}

The research and writing of this article were supported by a Traveling Fellowship and a Lindt Dissertation Fellowship from Columbia University, and a Mellon Postdoctoral Fellowship from the University of Pennsylvania. Special thanks to Bob Corbett, Jean-Léon Destiné, Michel Lamartinière Honorat, Louines Louinis, and Daniel A. Métraux.

1 A striking feature of the ethnographic literature on Haiti during the 1930s and 1940s - as Haiti was becoming a major site of international anthropological and sociological interest, and as Haitian ethnological studies were themselves in formation - is how many of the early monographs focus on Haitian popular religion, generally known as Vodou' ${ }^{1}$. This preponderance might not seem so surprising in and of itself, given both the centrality of these beliefs and practices to the lives of the great majority of Haitians at this time and, likewise, the extent to which constructions of «le vaudou» or «voodoo» had long been the metonymic sign of Haitian popular culture à l'étranger. Yet what was often not well acknowledged and sometimes went unmentioned altogether in this burgeoning ethnographic literature was that many of the popular ritual practices being studied, described, and analyzed were officially prohibited under Haitian law at the time. The 1835 and 1864 Haitian penal codes banned «le vaudoux» as a type of «sortilège» or spell-making, and this regime was reformulated and tightened a year after the end of the nineteen-year United States occupation of Haiti by President Sténio Vincent's 1935 décret-loi against «les pratiques superstitieuses»². 
One reason, presumably, why these successive penal laws have received scant attention in the voluminous ethnographic literature on popular religious practice in Haiti is that they tended not to be consistently or strictly enforced over the course of their cumulative 152year history ${ }^{3}$. A sustained application of the laws against socially-sanctioned religious practices was never politically feasible for Haitian authorities, given the strength of popular opposition against such a regime. However, these political considerations were not as inhibiting to foreign powers operating in Haiti, as borne out by persecution of Vodouisants during the US occupation of Haiti ending in 1934, and, shortly thereafter, during the Roman Catholic Church's most violent campaign against Haitian «superstition» in the late 1930s and early 1940s. Thus, in fact, the years when Haitian culture was first emerging as a major object of anthropological study both domestically and internationally were actually a period of prolonged penalization and persecution for many who served the Vodou spirits. Moreover, as I will explore below, the repression that marked this moment was itself, arguably, a major stimulus propelling both Haitian and international ethnography on what was variously termed «Vodou», «Vaudou», «Vodun», and «Voodoo» during these years. Swiss field ethnologist Alfred Métraux points to this link in writing about his travels with the writer Jacques Roumain in Haiti in the summer of 1941, at the height of the Church's "campagne anti-superstitieuse», when «[t]he scale of the offensive directed against Vaudou, and the brutality of the measures taken against its adepts appeared to me to bode its disappearance; this awakened in me the desire to undertake its study before it was too late." Describing their efforts to salvage sacred objects «which for scientific or aesthetic reasons, deserved to be spared» from the Church's bonfires, Métraux notes (1958: 13) that «Roumain was himself also convinced of the necessity to save the memory of Vaudou, so gravely threatened». According to Métraux, it was during this trip, in the course of their experiences and conversations, that Roumain conceived of establishing the national Bureau d'Ethnologie which he went on to found in Port-au-Prince in late October 1941, the government of President Élie Lescot supporting the collection and preservation of material cultures that, in effect, its own military backing for the Church's campaign at this moment was placing at risk. Early that November, Jean Price-Mars led a group of Haitian scholars in establishing the Institut d'Ethnologie as a private higher education faculty for ethnological training. 


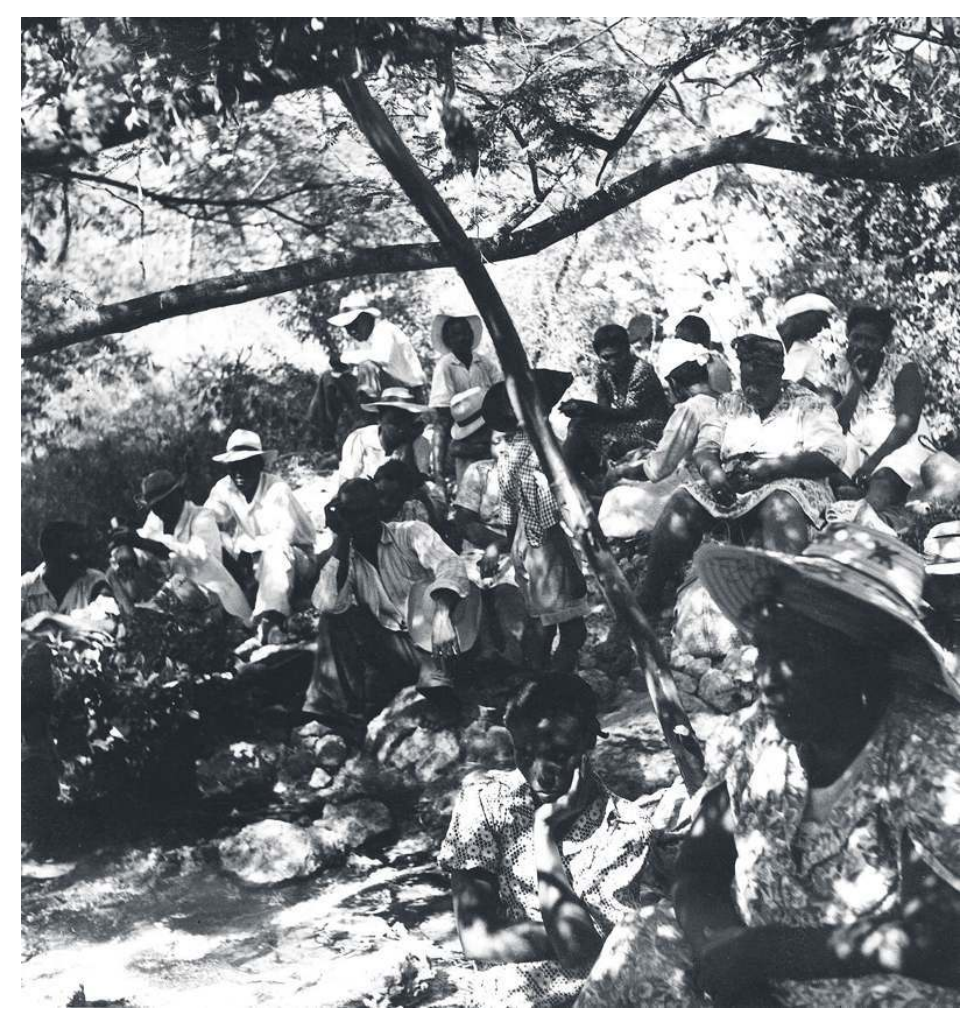

(c) Laboratoire d'Anthropologie sociale, rights reserved

In this article, then, I will examine both how the repression of popular religious practices in Haiti during the occupation and early post-occupation years became an impetus to ethnographic study on the parts of Haitian and foreign researchers, and how, to a greater extent than much of the published literature itself reflects, this regime conditioned the nature of the research that took place. I am particularly interested here in the relationship between the penalization and persecution of Vodouisants during these years and what seems to have been the widespread practice of «staging» ritual in the context of such ethnographic encounters. This phenomenon was not always simply a matter of the ethnographer's convenience or necessity. Indeed, sometimes practitioners recognized that framing their public ceremonies as demonstrations or "performances» for the benefit of visiting researchers was one way to ensure that local authorities would allow them to take place.

4 My characterization of such ethnographic events as «staged» or "performed» in this paper does not presuppose the existence of an "authentic» or "originary» cultural practice to which these reconstructions would bear a kind of secondary or inferior relation. In fact, this article seeks to deconstruct such conceptions, while still insisting on the specificity of the "performances» singled out here for analysis, which I argue were, in different ways and to differing degrees, framed or objectified as «ethnographic» among participants, observers, and/or authorities in the context of a particularly sustained and violent period of repression against the practice of Vodou in Haiti ${ }^{4}$. Thus, my aim is neither to impugn the "authenticity» of such events, nor to cast doubt on the credibility of the ethnographies that came, in part, from them. Rather, I am interested in studying the larger questions raised by the fact that the prohibition and persecution of popular 
ritual practices during and just after the US occupation seemed to become the occasion for their staged reenactment - in some instances strategically instigated by practitioners and in others, coerced and even performed by the authorities themselves. This history is particularly interesting in light of the centrality of staged demonstrations of «folklore» to public programs at the Bureau d'Ethnologie and to ethnological study at the Institut d'Ethnologie during the early to mid-1940s: indeed, the Bureau eventually organized its own in-house "chœur populaire» called Mater Dolorosa. In this article I intend to examine the relationship that each of these forms and instances of ethnographic "performance», including those presented for educational purposes, bore to the penal and ecclesiastical regimes against «superstitious practices» which were in force during the burgeoning of anthropological and ethnological work in Haiti during the late 1930s and 1940s.

\section{Penalization, ethnography, performance}

5 Such a study necessarily begins with the United States occupation of Haiti from 1915 to 1934, during which Marine enforcement of Haitian laws against «le vaudoux» as a form of sortilège was both severe and opportunistic. Not only did military officials frequently defend and justify the occupation as a «moral mission» with reference to their strict, literal-minded, and violent enforcement of this regime. They also encouraged the exploitation of this law (among others in the Haitian legal codes) in exacting labor and information from local communities. Yet marine memoirs and touristic accounts of Haiti during these years also make clear that, throughout the occupation, episodes of strict enforcement of the penal prohibition of Vodou often led to the displaced representation of the practices that the law prohibited, in some cases compelled by the law's enforcers themselves. In such instances, one might say, the «performative» moment of these laws ( i.e. their enforcement) gave rise to the staging of performative supplements of the rituals they banned.

6 Time and again during the occupation, the rigor with which marines enforced penal laws against les sortileges proved inconvenient to the desire of white North American travelers in Haiti who wished to see «voodoo ceremonies» - a desire no doubt heightened by the severity with which the prohibition was being applied. Selden Rodman, a prolific writer on Haiti and, particularly, on the «naïf» visual arts movement of the 1940s and 1950s, reported that when W. B. Seabrook, author of the infamous occupation travelogue The Magic Island «pled with Dr. Price-Mars to show him a ceremony, the Haitian scholar had to get special permission from the Commandant to "stage" one, engage a venerable houngan who couldn't find any drums, pay him $\$ 80$ - and finally be informed that it couldn't be managed! $\aleph^{5}$ However, there were also occasions when marines and gendarmes themselves became the agents of such attempts at performative "surrogation» ${ }^{6}$. Blair Niles, author of the 1926 memoir Black Haiti: A Biography of Africa's Eldest Daughter, recounted her visit to a gendarmerie post in the Artibonite Valley, where she was entertained by the four lieutenants stationed there, three Americans and one Haitian. Niles reports that when she expressed her interest in attending a ceremony, one of the American lieutenants teased his Haitian colleague, "Madame wants to see a Voodoo temple [...] Haven't you one to show her?"» Niles explained to her reader that, «Voodoo temples being against the law, and it being the duty of every member of the gendarme force to raid and abolish them, [the Haitian lieutenant] had no idea where such a temple 
could be found.» However, one of the prisoners then being held at the station was a drummer. So, after their lunch, a confiscated drum was produced, and this man was summoned to play for the American visitor as recorded in the accompanying photograph, captioned «The prisoner who drummed» (Niles 1926: 185-189). He is pictured in his striped prison uniform, seated on a hard-back chair, a conical drum angled between his knees, hands poised to strike the drum head a moment later - an image that documents succinctly, I think, how the prohibition and persecution of popular religious practices during the occupation became at times the occasion for their coerced, displaced reenactment.

7 On the other hand, when Melville and Frances Herskovits arrived in the town of Mirebalais (at the suggestion of Jean Price-Mars) in the summer of 1934, three months before the official end of the occupation, local practitioners quickly ascertained that these foreign visitors could be effective advocates in lobbying authorities for the permits necessary to mount prohibited sèvis. Herskovits's early diary entries from this trip reflect the extent to which US officials in Haiti sought to accommodate and facilitate his research, and how, on at least one occasion they intervened on his behalf against their own longstanding policy ${ }^{7}$. A few days after their arrival, Herskovits contacted the American Legation in Port-au-Prince because one of his informants had told him:

«...of an important ceremony for which there has been trouble in obtaining the necessary authorisation, this having been refused by Lieutenant Blaise, the commandant of this sub-district. Having in mind your offer to facilitate matters for us, I offered my good offices to help obtain the necessary permit from Port-auPrince, without, of course, mentioning any names or making any promises».

8 In his diary, Herskovits specifies that the Haitian lieutenant (stationed, incidentally, directly across the road from the house that the Herskovitses were renting) had «refused permission for an important "ceremonie" which would entail "feeding" the loas [spirits]. I have offered my good offices to help them, and if they get their authorisation, we may see something interesting ${ }^{8}$. As it happened, Blaise was on his way to Port-au-Prince the next day to take examinations for a promotion, and Herskovits wondered in his note to Norman Armour, the American minister in Haiti, if «his presence in the city might serve as an opportunity to pass on the word of which you spoke, and which might influence him in other instances of this nature». Armour, wrote back a few days later saying that this was a matter in "which we have to "watch our step" very carefully», but that he had discussed it with Major General Clayton C. Vogel, the final American commander of the Garde d'Haïti, who «is going to see Lieutenant Blaise, probably today, and have a talk with him. I hope this will have the general effect of helping matters along». Thus, Herskovits advised the woman whose family had been denied permission, to approach the lieutenant again, and this time, presumably on behalf of the intervention of the visiting researchers, authorization was granted. Herskovits describes attending this cycle of ceremonies in his diary in early July and notes that «since I had a hand in getting the authorisation it seems as though we are very welcome» ${ }^{9}$. Later that summer, he wrote back to Armour to let him know, «how much I appreciate the word you put in about my work here, with special reference to the ceremony of which I wrote you shortly after my arrival. Whatever you did, it worked wonders. The ceremony for which permission was desired was quite an important one, lasting four days, and we were able to see everything; more than that, it established our position here as nothing else could have done. As a result, work has gone on in excellent fashion $»^{10}$. 
9 The cycle of ceremonies on behalf of which Herskovits intervened seems to have been officially permitted by occupation and local authorities only because the visiting American researchers wished to attend them. In some sense, then, the ceremonies were authorized because they had been officially reframed as ethnographic "performances» of scientific interest to these foreign visitors ${ }^{11}$. While these ceremonies became the ethnographic basis for the ninth chapter of Life in a Haitian Valley (1937), «Vodun Worship: The Service», Herskovits does not mention the circumstances which prompted him to intervene, or the fact of that intervention itself in this book. His discussion of the regulation, penalization, and persecution of such public rituals under the US occupation in that monograph is limited to a paragraph in his penultimate chapter, where he notes that, according to his informants, Vodou had been "unmercifully suppressed by the Americans during the occupation", and that at this moment of transfer of authority in Mirebalais, «permission for vodun dances and for services must be obtained from the officer commanding the local detachment of the Garde d'Haïti, and this is not always granted. Penalties for illicit dances and ceremonies are severe, and because gossip is ubiquitous and no man lacks enemies, apprehension is prompt» (Herskovits 1971: 293).

This discussion of the issue of regulation and penalization might seem somewhat cursory in light of the number of times Herskovits reports in his field diary having heard complaints from informants both about the repression to which their religious practices had been subject under the occupation and about the regime that was then in effect. In the context of securing permission for the above-mentioned sèvis, Herskovits reported a conversation between his principal informant/interpreter, Léonce Joachim, and another visitor about «how difficult it is to get to [ceremonies where sacrifices are offered] because of the fact that they imprison for them, unless one knows the officials and these are willing to turn their backs» ${ }^{12}$. Even having received authorization for the sèvis through Herskovits's intercession, the woman who mounted them had thereafter been «summoned to the local Chef de Section to explain why she had not obtained permission [from him] for her dance last Saturday. Apparently that sort of harassing the Vodu people goes on all the time» ${ }^{13}$. It was Joachim's sense that authorities were actually stiffening the regulatory restrictions in advance of the imminent departure of the Marines that August.

11 This observation is notable in light of the post-occupation Haitian state's tightening of the official penal regime against what then became legally framed as «pratiques superstitieuses» a little over a year later. First, in early July 1935, the longstanding series of prohibitions collected under the penal category «des sortilèges» dating from 1864 was almost entirely revoked. Article 405, prohibiting the making of «ouangas, caprelatas, vaudoux, donpèdre, macandals and other sortilèges» and «[a]ll dances and any other practices of the nature to keep alive in the populations the spirit of fetishism and superstition", was abrogated, as was Article 407, entailing the seizure and destruction of «the instruments, utensils, and costumes used or destined to be used» in the accomplishment of such actions. Only Article 406, adapted from the French Code pénal, and banning the practices of fortune-telling, was left largely intact ${ }^{14}$. It is perhaps a little recognized fact of Haitian juridical history that for two months during the summer of 1935, Haiti was without a penal prohibition against most of the practices formerly classified as les sortilèges. Then on September 5, 1935, the government of President Sténio Vincent issued a «décret-loi» against «les pratiques superstitieuses», which were defined, primarily, as «the ceremonies, rites, dances, and meetings in the course of which are practiced, in offering to so-called divinities, sacrifices of cattle or fowl» ${ }^{15}$. Given Herskovits's several diary notes 
about the penalization of ceremonies in which such offerings were made to the gods the year before in Mirebalais, it would seem that perhaps the new law, while doubling the minimum prison sentences, and more than quadrupling the minimum fines from the 1864 law's levels, in some sense officialized an informal regulatory practice that was then already customary in certain parts of the country.

This analysis is also suggested by the work of American sociologist George Eaton Simpson, who conducted ethnographic research in northern Haiti in 1937 on a Social Science Research Council grant, and wrote in an article entitled "The Belief System of Haitian Vodun» (1945: 58), that "[t]he "dance without sacrifices" [had been] invented to circumvent the law» during the early years of US occupation. Simpson's published work and private correspondence reveal how closely he was in conversation with Herksovits and the latter's just-published Life in a Haitian Valley at the time of his fieldwork in Plaisance, Haiti. Yet to a greater extent than Herskovits or any of his several American colleagues working in Haiti during the mid-1930s, Simpson built discussion of the existing penal regime against Vodou - and, notably, its tightened enforcement at the time of his fieldwork - into his published work on Haitian popular religion ${ }^{16}$. What is more, as the above citation suggests, Simpson's ethnography documents the impact that the government's new official ban on animal sacrifice had on the performance of public ceremonies in northern Haiti, and the ways in which people negotiated this regime in continuing their private and public spiritual lives. He writes: «Some local officers who were on friendly terms with houngans ignored the new law, and others were bribed to allow ceremonies with sacrifices to be held on permits issued for bals. Sometimes members of a family held their ceremony in the privacy of a bedroom while a dance was in progress in the courtyard» (Simpson 1945: 58).

Simpson's articles likewise shed light on how Vodou elders and practitioners in Plaisance responded to his research and presence in the context of the still-recent memory of Marine persecution and the application of this new penal law ${ }^{17}$. In his article «Two Vodun-Related Ceremonies» (Simpson 1948), he describes how one of the most distinguished manbo in northern Haiti, Madame Ti-Nomme, had made a point of assuring him during a large celebration in honor of Saint James (in Kreyòl, Sen Jak), that «there was nothing on her altar except the images of the Saints, that there was nothing to conceal, and that everything was in accordance with Haitian law» (ibid.: 49-50). Such disclaimers highlight what must have been the ambiguous position of the several white male American researchers who worked in rural Haiti as the Marine occupation was ending, and in the years thereafter ${ }^{18}$. Her defensive response might also serve to contextualize Simpson's own disclosures that his research on religious ceremonies in Plaisance relied on enactments staged in the privacy of his house there. In his article "The Vodun Service in Northern Haiti» (1940a), Simpson acknowledges with characteristic candor that his composite description of a sèvis for the lwa was based on one ceremony he had attended in July 1937, the contributions of the novelist J. B. Cinéas who served as his interpreter, conversations with oungan and other practitioners, and "parts of ceremonies staged in my house on a number of occasions by informants some of whose relatives were houngans, or vodun priests" (ibid.: 236). In "Four Vodun Cerremonies» (1946: 154), he notes that «[t]he ceremonies given here were staged in my house near Plaisance on a number of occasions», and goes on to name several of those who took part in these performances (and presumably were remunerated in some way for them): Bertrand Velbrun, Terméus Joseph, Ulysse Marius, and Arsène Jean-Baptiste. 
Simpson does not specify whether such staging was a matter of ethnographic necessity or convenience - writing only that «it would have been impossible to obtain full accounts at actual ceremonies». Yet his discussion of how the recently tightened penal regime was conditioning the way in which sèvis were being performed, and his disclosures about the defensive responses of certain Vodou elders to his research and presence in Plaisance in 1937, may help explain why staging became, by his own acknowledgement, such a central and practical dimension of his research process in Haiti.

\section{Anti-superstitious missions and ethnographic salvage}

If Simpson's published writings on popular religion in Haiti stand out among those of his colleagues in documenting how state-prescribed penal regulation impacted peasant ritual practices and his own fieldwork, it was Alfred Métraux and Haitian poet, novelist, organizer of the Haitian Communist Party, and founder of the Bureau d'Ethnologie, Jacques Roumain who provided, respectively, the most important account (in Métraux's case) and analysis (in Roumain's case) of the Roman Catholic Church's «campagne antisuperstitieuse» several years later. Beginning in 1939, five years after the departure of the Marines, this campaign, popularly known as the kanpay rejete, was the Church's most sustained and violent offensive against the popular practice of Vodou in syncretic conjunction with Roman Catholicism, and notably as well, the growing influence of Protestantism in rural and urban Haiti at this time. Taking the 1935 law against «les pratiques superstitieuses» as an authorizing basis and American Marine and Protestant missionary assaults on popular religious communities as exemplary precedents, the Church organized a series of missions across the country to compel Haitians to practice a "pure» Catholicism. Those who refused to renounce «le mélange», were excluded from the Catholic sacraments, and those identified as oungan, manbo, or bòkò were subject to «anti-superstitious» raids led by local curés and groups of «rejetés», who aided in the destruction of «superstitious» objects and sites. In June 1941, President Lescot, Vincent's recently-elected successor, endorsed the Church's campaign and directed the Haitian "civil and military authorities to give their most complete assistance» to the Church's «mission [...] to combat fetishism and superstition ${ }^{19}$.

That May, Jacques Roumain returned to Haiti from a five-year peripatetic political exile in Brussels, Paris, Fort-de-France, New York, and Havana, during which time, even when forced to move because of political pressures, he seems to have planned his itinerary around the pursuit of anthropological training ${ }^{20}$. That summer as well, Alfred Métraux made his first trip to Haiti with his wife, fellow anthropologist Rhoda Bubendey Métraux, «somewhat prompted», he wrote to Herskovits beforehand, «by your excellent book In a Haitian Valley [sic]» to spend July and part of August in Haiti as «a deferred honeymoon and a well-deserved vacation $»^{21}$. Roumain and Alfred and Rhoda Métraux all arrived in Haiti at precisely the moment when the Church's crusade against «superstition» became a systematically administered series of raids across the provincial countryside: that is, prescribed by the Roman Catholic hierarchy, carried out by local priests accompanied by bands of rejetés, and enforced by local chefs de section and members of the US-trained Haitian Garde. In Le Vaudou haitien (1958), Métraux writes of witnessing firsthand the pillage and destruction that ensued, and pleading with curés to allow him to salvage certain pieces, «which for scientific or aesthetic reasons, deserved to be spared», from the piles of drums, vessels, images, and other objets superstitieux deposited behind 
presbyteries to be burned. A number of these he and Rhoda brought back to the United States and deposited in the Smithsonian Institution's collection ; others would come to form the core of the Bureau d'Ethnologie's collection. In mid-July, Alfred and Rhoda Métraux met up with Roumain, who accompanied them later that month on a trip to the Île de la Tortue, off Haiti's northern coast ${ }^{22}$. It was there, as noted earlier, that according to Métraux, he and Roumain discussed «sav[ing] the memory of Vaudou, so gravely threatened», through the creation of "a "Bureau d'Ethnologie" especially charged with this task» ${ }^{23}$.

In relating this narrative at the very beginning of Le Vaudou haitien, Métraux makes clear the extent to which he saw his subsequent research in Haiti (and the book itself) as a project of anthropological salvage, in which the sign or trace of a culture presumed doomed to extinction was preserved for posterity through ethnographic representation and/or collection (see Clifford 1988). Likewise, whether or not Roumain would have told the story of the Bureau's genesis in precisely the same way, his efforts to organize the Bureau d'Ethnologie immediately thereafter, in September and October of 1941, point, I would argue, to the way in which the Church's assault on popular religious belief, practice, and, in particular as far as Roumain was concerned, material cultures, served as a spur for his role in institutionalizing ethnological collection and study in Haiti at this moment. No writer identified with the then-burgeoning ethnological movement took a more prominent stand against the Church's «crusade» than Roumain, who published a three-part polemic in the Port-au-Prince daily Le Nouvelliste (which later appeared as a bilingul French/Spanish pamphlet entitled À propos de la campagne «anti-superstitieuse»/Las supersticiones...), and then, when this series provoked an immediate attack in the Catholic newspaper La Phalange, engaged between 30 March and 31 July 1942 in a wide-ranging debate with a member of the French clergy named Père Foisset over the premises, ends, and means of the Church's campaign, which, by then, the Catholic hierarchy had already suspended ${ }^{24}$. Yet, if he wrote powerfully and prolifically against the Church's offensive, Roumain, the historical materialist, was by no means a celebrant of Vodou in the manner of his colleagues in the Groupe des Griots. Indeed, beyond simply forecasting (as Métraux did) the religion's decline and eventual disappearance in his articles in Le Nouvelliste, Roumain made clear that he regarded the demise of Vodou as not just inevitable, but also salutary. He actively called for the peasantry to be freed «from their mystical shackles», not through an anti-superstitition campaign, but rather an "anti-misery» campaign, which would enable them to "overcome religious survivals rooted in their misery, ignorance, age-old exploitation» (Roumain 1942a: 12). Indeed, one of his principal objections to the Church's campaign was that he saw the performative violence of its anti-superstitious raids and bonfires as serving to instantiate the sacred powers of particular sites and things rather than to undermine them ${ }^{25}$ . His own research interest lay not, primarily, in studies of ritual, but rather in preColumbian archeology, and his stakes in organizing the Bureau seem to have focused on protecting and preserving this heritage in Haiti ${ }^{26}$. Indeed, he accused the foreign Catholic clergy of putting at risk and even looting the country's archaeological patrimony through the campagne anti-superstitieuse: the sculpted axe-heads called "pierres-tonnerres» (thunderstones) which formed part of the sacred relicry in many ounfo, for example, were targeted for confiscation, although interestestingly not for destruction by the Church as «pierres superstitieuses» (Roumain 1942b). 


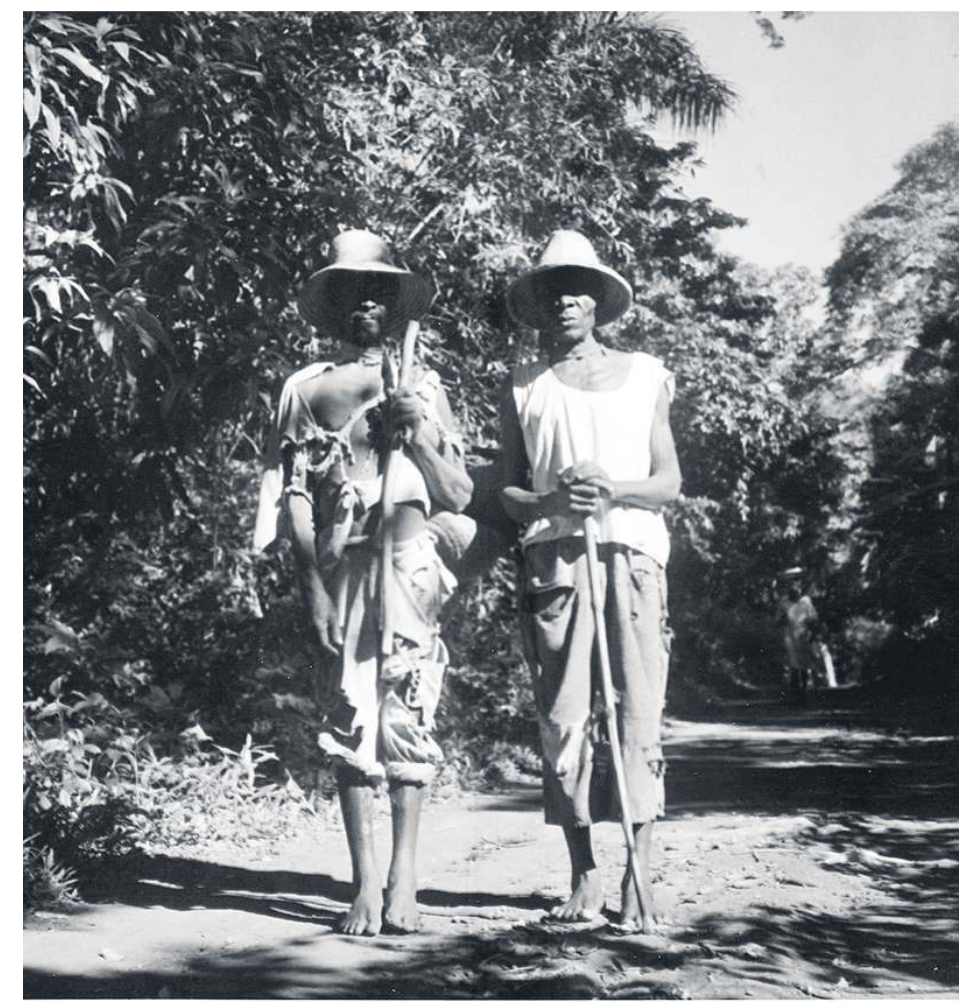

(c) musée du quai Branly

Yet Roumain also wrote one of the most significant works on Haitian popular religious ritual to be published during the early years of Haitian ethnological studies. His monograph, Le Sacrifice du Tambour-Assoto(r) (1943) focuses on the construction, baptism, and ritual uses of this towering drum of the Rada religious rite, distinguished, he wrote, for being not simply an «instrument of the diety», but also itself a «powerful Afro-Haitian God: Assoto Micho Tokodun Vodoun» (ibid.: 9). Roumain's choice to undertake an ethnography of the ceremonies of the asòtò drum stands out in light of the penal and ecclesiastical regimes that constrained and, at times, seem to have altogether prevented their observance in different parts of the country at that moment. Throughout the US occupation, the physical stature, sacred reknown, and relative rarity of these drums, had made them highly prized trophies among some marines, who exploited their raids on ounfo as occasions for confiscating and collecting «voodoo» memorabilia. The sheer size of these drums meant that they were difficult to conceal, and thus more subject to discovery and confiscation both during the occupation and, several years thereafter, during the Church's anti-superstitious missions ${ }^{27}$. Indeed, Métraux (1958: 164) writes that «most of the asòto disappeared during the anti-superstition campaign». What's more, of course, the cycle of animal offerings for the Rada lwa and, finally, for the spirit of the drum itself which Roumain describes in detail in his monograph were, since 1935, specifically prohibited by law as "pratiques superstitieuses». While this interdiction was by no means rigorously applied throughout the country, but rather adapted according to customary precedents and local practices, the ban on animal sacrifice was widely and often violently enforced in areas where the Church's «anti-superstitious» missions were active during its campaign. 

conducted his research, save that it took place over several months and that, among other informants, he was particularly grateful to «M. S. Abraham, who, in a very complex matter, has been for me a guide of an exceptional competence» (Roumain 1943: 3). This acknowldgment was to Saint Erlonge Abraham, a well-known Port-au-Prince oungan who was probably the Bureau's most important informant in its early years, and who later worked with Alfred Métraux (Oriol, Viaud \& Aubourg 1952: 40). According to the latter, Roumain's study of the asòto rituals depended on and performed a kind of surrogacy itself given that the strict enforcement of the penal law against Vodou during the campagne anti-superstitieuse made the elaborate cycle of ceremonies associated with the drum impossible to mount in Port-au-Prince and its vicinity. Métraux (1958: 164-165) writes that Roumain's article, «so rich in details on Vaudou ritual, was, unfortunately, not based on personal observations, but on the description of a ceremony which the houngan Abraham would have wished to celebrate», had he been able to.

If this was the case, I would suggest that it was precisely the fact that these ceremonies could not, effectively, be ritually performed at this moment which compelled Roumain to focus his only published study of ritual on the sacrifice of the asòtò drum. This may seem paradoxical, yet of course, the idea of recording for posterity what is presumed to be vanishing has long been an incentive for ethnographic research and representation. Métraux himself states as much explicitly in narrating, as noted before, how the «scale» and «brutality» of the Church's offensive against Haitian popular religion during the summer of 1941 «awakened in me the desire to undertake its study before it was too late», and likewise convinced Roumain «of the necessity to save the memory of Vaudou so gravely threatened» (ibid: 13). It is interesting to compare Roumain's portrait of the ceremonial cycle of the asòtò drum drawn, predominantly, it seems, from his work with Abraham, with Simpson's similarly composite and thus (as he acknowledges) idealized portraits of «The Vodun Service in Northern Haiti» and «Four Vodun Ceremonies», drawn principally from conversations with local practitioners and the staging of fragments of ceremonies at his house ${ }^{28}$. Both Roumain's monograph and Simpson's studies include extensive transcriptions of songs and prayers, as well as extraordinarily detailed and evocative descriptions of ritual. After transcribing a song sung for Ogou Feray in the course of the baptism of a new asòtò drum, Roumain, for example, writes:

«La danse qui accompagne le chant est essentiellement une danse Nago. Le mouvement est une sorte de balancement sur place d'avant en arrière, les genoux légèrement fléchis et les danseurs se déplacent insensiblement tournant lentement autour du poteau-mitan. Elle est dansée par groupes de quatre couples, les femmes de temps en temps faisant la révérence aux danseurs et ceux-ci les saluant en portant la main au front, ce qui s'appelle: faire serviteur. Mais il est de rigueur d'introduire le Nago par cette sorte de danse boitillante que nous avons déjà écrit [sic]: le Yanvalou» (Roumain 1943: 14-15).

It is almost as though not observing real ceremonies, or at least not having the opporunity to observe many, actually in some sense enabled the descriptive richness of Simpson's and Roumain's respective ethnographies. Simpson suggests as much in explaining and justifying his reliance on the staging of ritual: «It would be impossible to obtain full accounts at actual ceremonies. Since these rites are not highly standardized, they naturally vary from occasion to occasion» (Simpson 1946: 154). While Roumain does not specify how he worked with Abraham in researching his article and makes no mention of relying on staged reenactments of the kind that Simpson describes, his close, technical 
descriptions of ritual movement and dance, as evidenced in the passage quoted above, suggest that they may have figured as part of his research process as well.

\section{Popular dances or «superstitious practices»}

21 It is interesting to note, in the context of Simpson's and possibly Roumain's reliance on such modes of research, that the staging of ritual came to have an institutionalized place in Haitian ethnographic research and pedagogy from the founding of the Bureau and Institut d'Ethnologie in October-November 1941. Early students at the Institut, such as Jean-Léon Destiné (who went on to become an internationally celebrated performer and choreographer of Haitian «folklore» dance) remember that their courses frequently featured staged demonstrations of ritual repertories: «That is how we learned. As they [informants] danced in front of us, we would analyze the steps, trying to see what they meant, trying to see the background, and the interpenetration of the songs and rhythms. Naturally we also learned from books, but we got to associate what we read with what we saw ${ }^{29}$. Staged representations of popular and ritual forms were likewise a featured aspect of the Bureau d'Ethnologie's public programming, particularly after Roumain left its directorship in November 1942 to become Haiti's chargé d'affaires to Mexico ${ }^{30}$. Lorimer Denis, then head of the Bureau's Section d'Ethnographie Afro-Haïtienne, exerted a greater influence over the institution's programming thereafter, and was instrumental in establishing the performative orientation of a series of public lectures inaugurated that November. The first of these, René Victor's talk on "Les Voix de Nos Rues», was accompanied by popular songs sung by students from the École Normale d'Agriculture ${ }^{31}$. Shortly thereafter, the Bureau formed its own in-house troupe of performers, the aforementioned «Mater Dolorosa.» Billed as Haiti's first "chour populaire folklorique», Mater Dolorosa was assembled and directed by Saint Erlonge Abraham, the same houngan who had been Roumain's principal informant on the asòto article. With the support of Denis, Abraham assembled a group of about a dozen performers, mostly women, drawn from his own sosyete in the Port-au-Prince neighborhood of Fort Saint Clair ${ }^{32}$. Mater Dolorosa performed ritual songs and dances for the Bureau's second public lecture in the spring of 1943, a presentation by Lorimer Denis entitled «De l'évolution stadiale du vodou», written in collaboration with François Duvalier, as well as for several subsequent talks and a Bureau-sponsored «gala folklorique».

I do not mean to argue here that the staging of such performances and demonstrations at the Bureau d'Ethnologie and Institut d'Ethnologie was directly compelled by the penalization and persecution of popular religious practice in Haiti during the years when ethnological study was being institutionalized in Haiti. Yet, I would argue that there is still a connection to be drawn between such staged ethnographic representations and the penal regime against Vodou at this moment, particularly when the former are situated in the larger context of theatrical staged folklore in Port-au-Prince during the early 1940s and, most especially, the post-occupation state's own investment in promoting folkloric constructions of Haitian popular music and dance as images of Haitian national culture abroad. In an earlier article, I examined how the 1935 law against «pratiques superstitieuses» affirmed the right of peasants to organize "popular dances», while at the same time severely tightening the interdiction of rituals the state deemed «liable to foster superstitious beliefs harmful to the good name of the country» - most particularly, the sacrifice of animals as offerings to «so-called divinities». It must be recognized that 
the primitivist and sensationalist images of «voodoo» which proliferated over the course of the US occupation and thereafter in American travelogues, marine memoirs, horror cinema, etc. played a forceful role in the state's redefinition and tightening of the penal regime against Vodou after the restoration of Haitian sovereignty. Yet the formulation of this law also illuminates, I think, how closely tied the state's penalization of Vodou was to its promotion of staged folklore performance as the image of Haitian national culture abroad; how, in other words, there was more consistency than contradiction in the Lescot government's sponsorship of the Church's campagne anti-superstitieuse during the very same months that it sponsored the appearance of a Haitian folklore troupe at the National Folk Festival in Washington, DC, and the founding of the Bureau d'Ethnologie. It seems to me that the 1935 law's distinction between officially sanctioned «popular dances» and officially prohibited «superstitious practices» also underwrote the postoccupation state's promotion of popular performance cultures as a transcended or soonto-be surpassed «national folklore».

In this article I have tried to show how the penal and ecclesiastic regimes against Vodou during the 1930s and early 1940s served as an incentive for the flourishing of ethnographic work on Haitian popular religion at that time, and also how, to a greater extent than is acknowledged in the published literature itself, they also conditioned the nature and forms that this early research took. I have been particularly interested in cases in which the prohibition and persecution of ritual practices seemed to produce performative and textual «surrogates» of what was banned, from the ethnographicallyframed ceremony which the Herskovitses attended, to the staging of fragments of sèvis in Simpson's home in Plaisance, to Roumain's detailed descriptions of rituals that, according to Métraux, Abraham was unable to mount, to, arguably, the state's sponsorship of folkloric performance as the image of post-occupation national culture.

Yet it is striking that while the persecution of Vodou spurred anthropological and ethnological work on Haitian popular religious practice, the ethnographies produced by Haitian and foreign researchers during these years rarely explicitly critiqued the penal laws which served as the authorizing basis for the overlapping US marine, Protestant missionary, and Catholic «anti-superstitious» offensives. Throughout his long writing career Jean Price-Mars was a notable exception to this silence, beginning, in Ainsi parla l'oncle, with his reclassification of Vodou as a religion, and thus, implicitly, not a form of «sortilèges» as it was then constructed and criminalized under penal law ${ }^{33}$. Then, in 1941, a lawyer and affiliate of the Griots group named Kléber Georges-Jacob argued in an anthology of his writings, L'Ethnie haitienne, that, on the basis of Price-Mars's scholarly redefinition, the legal identification of Vodou as a "pratique superstitieuse» was incorrect, and its prohibition, unconstitutional, since citizens were endowed with the right to practice their religion as long as it did not disturb the public order ${ }^{34}$. Outside of Price-Mars's and Georges-Jacob's writings, however, outright calls for the lifting of the interdiction against les pratiques superstitieuses during the late 1930s and 1940s were extremely rare in the growing social scientific corpus on Haitian popular religion. Later in the 1940s, Emmanuel C. Paul, a professor at the Bureau d'Ethno-logie, noted the paucity of ethnological legal studies more generally, and challenged his colleagues to develop this area, towards a reform of the Haitian legal system. He proposed that the publication of even «ten or so monographs on our juridical folklore would furnish our jurists with enough material for the first steps in elaborating [a] Haitian law» ${ }^{35}$. While the decriminalization of popular religious rituals seems implicit to this project, Paul does not 
make specific reference to it. The published ethnographic and ethnohistorical writings of collaborators Lorimer Denis and François Duvalier on Vodou in the late 1930s and early 1940s make no reference to the penal interdiction of the religion, and thus, while describing Vodou as «the crystallization of the origins and the psychology of the Haitian people», their work posed no challenge to this regime ${ }^{36}$.

The reasons why contesting the penalization of Vodou did not become a greater cause among those who researched and wrote ethnographies on Haitian popular religion in the 1930s and 1940s are various, having as much to do with political ideology as disciplinary convention. On the one hand, the cultural determinism of Herskovits's project and the cultural essentialism of that of Denis and Duvalier sidelined the dialectics of power produced by these legal regimes. On the other hand, Roumain's view, emerging from his Marxism, that Haitian popular religious belief was a symptom of popular misery which education and the transformation of material conditions would inevitably dispel, made him an unlikely adversary of this legislation. Métraux, as I noted above, was convinced that Vodou was already in an advanced state of decline, hastened by state and Church persecution and «voodoo tourism» which intensified during the 1940s and early 1950s, but inevitable in any case: «I am not the apologist of Vodou», he wrote in Le Vaudou haitien, «and I know that sooner or later it must disappear». Born of the assumption that Haitian popular religious belief and practice was external to and incompatible with Western modernity, this view translated, professionally, into collection and documentation rather than advocacy. Yet it is in great measure thanks to Métraux and his extensive account of the campagne anti-superstitieuse that we have as thorough an understanding of the penalization and persecution of Vodou during these years as we do. If comparatively little was written on the juridical and customary laws which shaped popular religious practice, and which were themselves, in turn, shaped by popular belief and political will, Métraux's writings and those of the other scholars I have discussed above nevertheless exemplify how these regimes must be understood as a crucial influence on the flourishing of ethnography in and on Haiti during the 1930s and 1940s, as well as on the nature and the forms that this research took.

\section{BIBLIOGRAPHY}

CLIFFORD, James

1988 «On Collecting Art and Cultures», in J. Clifford, The Predicament of Culture: Twentieth-Century Ethnography, Literature and Art. Cambridge, MA, Harvard University Press: 215-251.

CORVINGTON, Georges

1991 Port-au-Prince au cours des ans: la ville contemporaine, 1934-1950. Port-au-Prince, Imprimerie Henri Deschamps.

DENIS, Lorimer \& DUVALIER, François

1944 « L'évolution stadiale du vodou », Bulletin du Bureau d'Ethnologie, 3 : 9-32. 
DUNHAM, Katherine

1994 Island Possessed. Chicago, University of Chicago Press (1st ed. 1969).

FOWLER, Carolyn

1980 A Knot in the Thread: The Life and Work of Jacques Roumain. Washington, DC, Howard University Press.

GEORGES-JACOB, Kléber

1941 L'Ethnie haïtienne. Port-au-Prince, Imprimerie de l'État.

HERSKOVITS, Melville J.

1971 Life in a Haitian Valley. Garden City, Doubleday and Co. (1st ed. 1937).

HOFFMANN, Léon-François

1990 Haït : couleurs, croyances, créole. Montréal, CIDIHCA/Port-au-Prince, Éditions Henri

Deschamps.

HURBON, Laënnec

1987a Le Barbare imaginaire. Port-au-Prince, Éditions Henri Deschamps.

1987b Comprendre Haïti: essai sur l'État, la nation, la culture. Port-au-Prince, Éditions Henri

Deschamps.

MÉTRAUX, Alfred, 1958 Le Vaudou haïtien. Paris, Gallimard.

1978 Itinéraires 1 (1935-1953. Carnets de notes et journaux de voyage. Ed., introd., notes by AndréMarcel d'Ans. Paris, Payot.

NILES, Blair

1926 Black Haiti: A Biography of Africa's Eldest Daughter. New York, Grosset \& Dunlap.

ORIOL, Jacques, VIAUD, Léonce \& AUBOURG, Michel

1952 Le Mouvement folklorique en Haïti. Introduction de Lorimer Denis et François Duvalier. Portau-Prince, Imprimerie de l'État.

PAUL, Emmanuel C.

1949 L'Ethnographie en Haiti: ses initiateurs, son état actuel, ses taches et son avenir. Port-au-Prince, Imprimerie de l'État.

PRICE-MARS, Jean

1929 Une étape de l'évolution haïtienne. Port-au-Prince, Imprimerie « La Presse ».

1951 Folklore et Patriotisme, conférence prononcée sous les auspices de l'Alliance Française le 24 novembre. Port-au-Prince, Imprimerie Les Presses libres.

RAMSEY, Kate

2002 «Without One Ritual Note: Folklore Performance and the Haitian State,

1935-1946», Radical History Review, 84:7-42.

ROACH, Joseph

1996 Cities of the Dead: Circum-Atlantic Performance. New York, Columbia University Press.

RODMAN, Selden 
1961 Haiti: The Black Republic. New York, Devin-Adair Co.

ROUMAIN, Jacques

1942a À propos de la campagne «anti-superstitieuse/Las supersticiones... Port-au-Prince, Imprimerie de l'État.

1942 b « Réplique finale au R. P. Foisset, VIII », Le Nouvelliste, 30 Juillet.

1943 Le Sacrifice du Tambour-Assoto(r). Port-au-Prince, Imprimerie de l'État.

SIMPSON, George Eaton

1940a «The Vodun Service in Northern Haiti», American Anthropologist, 42 (2): 236-237.

1940b «Haitian Magic », Social Forces, 19 (1): 95-100.

1945 «The Belief System of Haitian Vodun», American Anthropologist, 47 (1): 35-39.

1946 «Four Vodun Ceremonies», Journal of American Folklore, 59, 232: 154-167.

1948 «Two Vodun-Related Ceremonies», Journal of American Folklore, 61, 239 : 49-52.

TROUILLOT, Duverneau

1885 Esquisse ethnographique: le vaudoun, aperçu historique et évolutions. Port-au-Prince, Imprimerie R. Ethéart.

\section{NOTES}

1. The meanings that have been ascribed to this sign over the course of more than two centuries of writings by, primarily, outsiders are as numerous as the spellings advanced by the same, including "vaudoux», «voodoo», " audou», «vodun», and "vodoun». So as not to smooth over the ideological differences, phonetic debates, and political controversies that have marked such usages, I will maintain these different spellings in the citations in which they appear. Likewise, while spelling words such as « oungan» (male priest) and «manbo» (female priest) in the ways that are now officially standardized, I will preserve the orthographies « houngan» and «mambo» where they appear in quotations from older sources.

2. The first Haitian Code pénal, promulgated in 1835, stipulated that «All makers of ouangas, caprelatas, vaudoux, donpèdre, macandals and other spells, will be punished by one to six months of imprisonment, and a fine of 16 to 35 gourdes; not taking into consideration the stronger sentences that they might incur for offenses or crimes committed in preparing or carrying out their evil spells»; the 1864 Code pénal tightened and expanded this prohibition to include, "All dances and any other practices that are of a nature to maintain the spirit of fetishism and superstition in populations»; and the 1935 decree-law banned as «superstitious practices»: 1) the ceremonies, rites, .../........ dances, and meetings in the course of which are practiced, in offering to so-called divinities, sacrifices of cattle or fowl; 2) the act of exploiting the public in making believe that, by occult means, it is possible to manage either to change the situation of fortune of an individual, or to heal him of any illness, by processes unknown to medical science; 3) the fact of having in one's residence cabalistic objects serving to exploit the credulity or the naivete of the public. This law was repealed by the 1987 Haitian Constitution following the overthrow of the Duvalier dictatorship. In April 2003 the government of President Jean-Bertrand Aristide officially recognized Vodou as a «national religion». All translations are mine unless otherwise noted. 
3. Jean Price-Mars (1951) and, more recently, sociologist Laënnec Hurbon (1987a, 1987b) and literary scholar Léon-François Hoffmann (1990) offer major exceptions to this oversight and this article is indebted to their writings. Other scholars who have argued for the reinterpretation or overturning of these laws historically include, most notably, Duverneau Trouillot (1885) and Kléber Georges-Jacob (1941)

4. I am grateful to Kevin Yelvington for his incisive questions and comments on these issues.

5. Selden Rodman (1961: 68). In critiquing Seabrook's book in his Une étape de l'évolution haïtienne (1929), Price-Mars writes (1929: 161) that he had tried to assist the American author in the latter's efforts to attend « des cérémonies vaudouesques» while in Haiti. However, he notes, «j'ai échoué dans mes démarches, parce que j'ai rencontré une méfiance obstinée de la part de tous les paysans auxquels je me suis adressé malgré mes relations vieilles et cordiales avec eux».

6. «Performance stands in for an elusive entity that it is not but that it must vainly aspire both to embody and to replace. Hence flourish the abiding yet vexed affinities between performance and memory, out of which blossom the most florid nostalgias for authenticity and origin» (Roach 1996: 3-4).

7. «I phoned Mr. Armour, the American minister, shortly before noon, and we went over at once. He is a charming man, as is Drew, the Secretary of the Legation. We are assured of all cooperation from him, and this promise he has made good in excellent fashion [...] The Legation people had arranged for me to meet General Vogel, the Commander of the Garde d'Haiti, and I had to go to see him and get a letter to the young Lieutenant at Mirebalais which would permit us to work undisturbed. His office is also arranging for the permit to take pictures from the Secretary of the Interior. Armour came to the home [...] to offer all aid once again», Melville J. Herskovits, «Haiti Diary ", 22 June 1934, Melville J. and Frances S. Herskovits Papers, MG 261, Schomburg Center for Research in Black Culture, Box 13, Folder 68, p. 1 and p. 4.

8. Herskovits, «Haiti Diary », 22 June 1934, p. 8.

9. Herskovits, «Haiti Diary », 6 July 1934, p. 24.

10. Letter from Melville J. Herskovits to Norman Armour, 22 June 1934; letter from Armour to Herskovits, 27 June 1934; letter from Herskovits to Armour, 7 August 1934, in «Haiti Field Trip » file, Box 8, Folder 22, Melville J. Herskovits Papers, Northwestern University Library. My gratitude to the archivists who assisted my research in this collection.

11. This episode underscores that such events were framed in multiple ways depending on the subject positions and perspectives of those involved. Here, the family on whose behalf Herskovits intervened was not only aware of this reframing, but also tactically involved in engineering it; yet this did not mean, of course, that they regarded the sèvis that took place as diminished or altered in spiritual force, sensibility, and efficacy on account of it.

12. Herskovits, «Haiti Diary », 2 July 1934,"p. 22.

13. Herskovits, «Haiti Diary ", 24 July 1934, p. 50. Herskovits notes, «we will go to the new Lieutenant concerning the matter if it isn't settled».The problem in this case, as explained to Herskovits, was that «new regulations from Port-au-Prince make it necessary to obtain authorization from the head of the guards in a given district, not from a chef de section». However, given the force of customary tradition, this woman found herself on the wrong side of the local chef de section in not seeking his permission - and paying him the fee which the latter entailed. Thus, even when the law was not being enforced strictly or violently, the criminalization of Vodou became the pretext for informal regulation and graft on the part of local authorities.

14. Only the second line of article 406, specifying that the sentences for the crimes listed in articles 405 and 406 were to be served in labor camps at maritime prisons, was deleted.

15. Décret-loi sur les pratiques superstitieuses, Bulletin des lois et actes, 1934-35, Port-au-Prince, Imprimerie de l'État, 1935, p. 351.

16. «In 1937 the government was enforcing the laws against vôdoun in an attempt to stamp it out. These efforts had little effect except to reduce the number of public ceremonies» (Simpson 
$1940 \mathrm{~b}: 100)$. Simpson also recounts that many of his informants regretted the constraining effect that the occupation had on the duration of important annual sèvis: whereas, in an earlier generation, these could have lasted for nearly a month, since the occupation they were abbreviated to less than a week (Simpson 1940a : 237). Elsewhere, Simpson (1945: 58) also discusses how «[e]ven where local officials were not opposed to the cult, the poverty of peasants during the middle and late thirties prevented them from staging elaborate ceremonies» .

17. Haiti became a major field research site for American ethnographers during the late occupation years and thereafter. Elsie Clews Parsons visited in 1926; Harold Courlander first traveled to Haiti in 1932 and .../.......... spent much of the next decade in residence in Port-auPrince; the Herskovitses arrived for their three-month stay in the summer of 1934; in 1935-1936 Katherine Dunham, then a student of anthropology at the University of Chicago, spent nine months in Haiti researching social and ritual dance under Herskovits's direction. In early 1937, Harold Courlander, Zora Neale Hurston, Alan Lomax, Lydia Parrish, and George Eaton Simpson were all conducting research in Haiti.

18. In the same way, Michel Lamartinière Honorat, who was one of the young Haitian ethnologists who took part in the Unesco-funded sociological survey of the Marbial Valley that Alfred Métraux led from 1948-1950, told me that at first some Vodouisants perceived this investigation as the campagne anti-superstitieuse all over again, and did not want to tell the researchers anything (Interview with author, Pétionville, Haiti, 4 June 1997). Métraux reported that the Church's crusade had been particularly violent in this region.

19. Campagne anti-superstitieuse: documentation, n.p., 1941, p. 112. Collected at the Bibliothèque haïtienne des Pères du Saint Esprit, Port-au-Prince. My gratitude to Ephèle Milce and Sabrina Réveil at the Bibliothèque haïtienne for their invaluable assistance with this research.

20. Roumain returned to Port-au-Prince in May 1941, following the election of Élie Lescot, who had signaled during his campaign that opponents of the former government in exile would be welcomed home should he become president. See Fowler (1980: 175-211). See also letters from Jacques Roumain to Melville J. Herskovits 6 June 1939 and 4 August 1939. In Jacques Roumain file, Melville J. Herskovits Papers, Northwestern University Library.

21. Métraux had written to Herskovits that June to solicit advice: «This trip of mine is by no means anthropological [...]. But as I happen to be a man who loaths [sic] tourism, tourists, and everything smacking of sightseeing, please tell me where to go to have the illusion of doing fieldwork and to get the feel of real Haitian life», Letter from Alfred Métraux to Melville J. Herskovits, 3 June 1941. In Alfred Métraux 1936-1941 file, Box 13, Folder 25, Melville J. Herskovits Papers, Northwestern University Library.

22. Métraux's journal entries from this trip reveal the extent to which he and Rhoda's travels with Roumain were focused on the collection of pre-Columbian pottery fragments, axe-heads, and pestles, which they purchased from locals and searched for themselves in caves identified as «trou-zind» (trous des Indiens). See Métraux 1978: 133-142.

23. Métraux (1958: 13). Before leaving Haiti, Métraux gave a talk encouraging the establishment of such a center. See Corvington (1991: 235). Interestingly, Métraux does not mention discussing the creation of such an institution with Roumain in his journal from this trip. However, in the midst of their travels together, on 1 August 1941, Métraux (1978: 139) recorded an entry which may shed light on why he later claimed to have been an influence on Roumain's founding of the Bureau: «Quarrel with Roumain who expresses the most derogatory views on museums. I feel irritated beyond control and reason.»

24. Joseph Le Gouaze, Archbishop of Port-au-Prince, advised curés in a confidential letter of March 20, 1942 that the missions anti-superstitieuses were to be indefinitely postponed, even while assuring them that the «anti-superstitious crusade» must continue as it was the Church's «raison d'être» «Communication de Son Exc. Mgr l'Archevêque de Port-au-Prince», 20 March 1942. Collected at the Bibliothèque Haïtienne des Pères du Saint Esprit, Port-au-Prince. 
25. «[L]a frayeur de l'enfer n'a pas radicalement bouleversé leur conception religieuse. Elles n'ont pas renoncé à croire aux loas, mais seulement à les servir. Le Clergé lui-même a contribué à maintenir la croyance en la présence des loas: en les combattant comme une réalité redoutable, en abattant par exemple certains arbres sous prétexte d'en chasser les mauvais esprits: ce qui, pour les paysans, passait pour la confirmation évidente de leur existence» (Roumain 1942a: 11).

26. In Brussels, for example, Roumain had met specialists in pre-Columbian archeology and read extensively in this area. See Fowler (1980: 175-176). In one of his 1939 letters to Herskovits, Roumain wrote that, in continuing his anthropological studies in the United States, he hoped to be able «to bring forth my book on the pre-Columbian ethnology of Haiti». Letter from Jacques Roumain to Melville J. Herskovits, 6 June 1939. Herskovits Papers, Northwestern University Library.

27. At the beginning of her ethnographic memoir Island Possessed, Katherine Dunham (1994: 3) writes that «[w]hen I arrived in Haiti, not long after the exodus of the Marines, there were still baptized drums hidden in hollow tree trunks and behind waterfalls».

28. See Emmanuel C. Paul's critique of Roumain's tendency to idealize in this study, which he nevertheless credits as being the first monograph of the Haitian ethnological corpus: «Quand il parle de la cérémonie de l'Assotor, il a semblé y voir une constante dans le culte populaire. Selon certains informateurs, cette cérémonie ne serait pas connue partout. Il semble même que son aire d'extension ne dépasse pas une partie des départements de l'Ouest et du Sud. Et même là, elle est peu usitée: elle ne peut se renouveler fréquemment à cause des frais trop élevés qu'elle exige: $\$ 1.000 .00$ ou Gdes. 5.000.00. [...] Par ailleurs, nous avons bien peur que cet ouvrage ait été écrit sous la dictée d'un unique informateur, celui mentionné dans la preface: M. Abraham, houngan de son état» (Paul 1949: 25, 26).

29. Jean-Léon Destiné, interview with the author, New York City, 21 January 1992. Quoted in Kate Ramsey (2002: 16).

30. Roumain died two years after assuming this post at age 37 .

31. «La Conférence de R. Victor. Elle fut prononcée samedi à l'Hôtel de Ville, en présence d'un auditoire de choix», Haïti-Journal, 23 November 1942.

32. The ethnologist Michel Lamartinière Honorat recalled that Lorimer Denis was instrumental in forming Mater Dolorosa, and gave the troupe its name (Interview with the author, Pétionville, Haiti, 4 June 1997). The folklore performer and choreographer Louines Louinis clarified that Abraham was from this neighborhood in Port-au-Prince, and remembered that the members of Mater Dolorosa were drawn from Abraham's religious family. (Interview with the author, Brooklyn, NY, 19 July 1998). Mater Dolorosa's most celebrated performer, Marie-Noël, was, as Métraux identifies at one point (1958: 224-225), the " reine-chanterelle ", of Abraham's sosyete. See also the tribute published upon her death in Le Bulletin du Bureau d'Ethnologie, «Hommage à Marie-Noël», March 1947, pp. 27-31.

33. Later on, in a 1951 lecture, «Folklore et patriotisme», probably his strongest published statement against the legal prohibition of Vodou, Price-Mars built on this earlier redefinition in arguing against the injustice of the law's failure " to disassociate archaic and old-fashioned religious practices from crimes of sorcery and magic » (Price-Mars 1951: 17-18).

34. Georges-Jacob (1941: 74). He continues: «Pour justifier l'interdiction du Vodou haïtien, le législateur fait état de l'ordre public. L'ordre public, pensons-nous, ne saurait ici entrer en ligne de compte, vu que le culte vodouesque revêt en notre Pays un caractère purement familial. Les cérémonies ont lieu dans les villes à l'intérieur des maisons; dans les campagnes et les plaines, à l'air libre, sous les tonnelles et dans le respect révérentiel des lieux saints. Donc aucune atteinte morale ou matérielle n'est portée au droit de la société. Le législateur commet une lourde faute en voulant pénaliser des actes qui ne constituent pas un danger immédiat ni médiat pour la société.» 
35. Paul writes (1949: 35): «Si notre législation était rédigée toujours en fonction d'une profonde connaissance de notre peuple, elle eût certainement perdu sa qualité d'emprunt et nous eussions assisté à l'élaboration d'un droit spécifiquement haïtien, épousant la courbe de nos besoins et de nos aspirations et nullement étranger aux normes occidentales. Mais ne devons-nous pas attribuer à une ignorance coupable le fait par exemple que notre code rural est un pastiche du code rural français?»

36. Denis \& Duvalier (1944: 23). Of course, the elder Duvalier exploited the iconography of Vodou, and instrumentalized its social organization as best he could in consolidating dictatorial power. He did not repeal the law against «les pratiques superstitieuses» during his «présidence à vie»; and nor did his son and successor, Jean-Claude Duvalier. As noted earlier, this law was repealed following the overthrow of the dictatorship with the passage of the 1987 Haitian Constitution.

\section{ABSTRACTS}

A preponderance of the ethnographies published by researchers working in Haiti during the 1930s and 1940s focus on the Vodou religion. Yet the fact that many Haitian popular ritual practices were officially prohibited by penal law, first as «sortilèges» and later as "pratiques superstitieuses», and, on this basis, subject to US Marine, Protestant missionary, Catholic Church, and Haitian state offensives during these same years, is not always well-acknowledged or documented in this ethnographic literature. Focusing on the writings of Melvillle J. Herskovits, George Eaton Simpson, Jacques Roumain and Alfred Métraux, this article argues that the persecution of Haitian popular religious practices played a key role in propelling ethnographic work on Haiti and Vodou during this period and also influenced the methodological forms that this research took. In particular, the article examines the ways in which officially prohibited rituals were restaged and reframed as ethnographic «performances» in the context of this repression.

Alors qu'un grand nombre des études ethnographiques de chercheurs travaillant sur Haïti pendant les années 1930-1950 porte sur la religion vodou, cette littérature ne fait que peu état ni n'approfondit le fait que la plupart des pratiques rituelles populaires, considérées comme «sortilèges» ou «pratiques superstitieuses», étaient alors officiellement interdites par la loi et furent de ce fait violemment réprimées, tant par l'armée américaine d'occupation, que par les missions protestantes, l'Église catholique et l'État haïtien. Se basant sur les écrits de Melville J. Herskovits, George Eaton Simpson, Jacques Roumain et Alfred Métraux, l'auteur souligne que la persécution qu'ont subie les pratiques religieuses populaires a cependant joué un rôle majeur dans la dynamique prise par les études ethnographiques sur Haïti et le vodou et a également influencé les formes méthodologiques qu'ont prises ces recherches. L'article se penche plus particulièrement sur la façon dont les rituels, officiellement interdits, furent pourtant remis en scène et réélaborés dans le cadre de «représentations» ethnographiques. 
INDEX

Keywords: afro-American anthropology, Haitian ethnology, law, performance, vodou

Mots-clés: anthropologie afro-américaine, ethnologie haïtienne, loi, performance, vodou

\section{AUTHOR}

KATE RAMSEY

Princeton, NJ ramseykate@yahoo.com 